Article

\title{
Fluoxetine Removal from Aqueous Solutions Using a Lignocellulosic Substrate Colonized by the White-Rot Fungus Pleurotus ostreatus
}

\author{
Andreia D. M. Silva ${ }^{1}\left(\mathbb{D}\right.$, Juliana Sousa ${ }^{1}$, Malin Hultberg ${ }^{2}\left(\mathbb{D}\right.$, Sónia A. Figueiredo ${ }^{1} \mathbb{D}$, Olga M. Freitas ${ }^{1, *(\mathbb{D})}$ \\ and Cristina Delerue-Matos ${ }^{1}$ (D)
}

check for

updates

Citation: Silva, A.D.M.; Sousa, J.;

Hultberg, M.; Figueiredo, S.A.;

Freitas, O.M.; Delerue-Matos, C.

Fluoxetine Removal from Aqueous

Solutions Using a Lignocellulosic

Substrate Colonized by the White-

Rot Fungus Pleurotus ostreatus. Int. J.

Environ. Res. Public Health 2022, 19,

2672. https://doi.org/10.3390/

ijerph19052672

Academic Editor: Paul B. Tchounwou

Received: 24 January 2022

Accepted: 23 February 2022

Published: 25 February 2022

Publisher's Note: MDPI stays neutral with regard to jurisdictional claims in published maps and institutional affiliations.

Copyright: () 2022 by the authors Licensee MDPI, Basel, Switzerland. This article is an open access article distributed under the terms and conditions of the Creative Commons Attribution (CC BY) license (https:// creativecommons.org/licenses/by/ $4.0 /)$.
1 REQUIMTE/LAQV-Associated Laboratory for Green Chemistry (LAQV) of the Network of Chemistry and Technology (REQUIMTE), Instituto Superior de Engenharia do Porto, 4200-072 Porto, Portugal; andreia.silva@graq.isep.ipp.pt (A.D.M.S.); 1191179@isep.ipp.pt (J.S.); saf@isep.ipp.pt (S.A.F.); cmm@isep.ipp.pt (C.D.-M.)

2 Department of Biosystems and Technology, Swedish University of Agricultural Sciences, Alnarp, 23053 Skara, Sweden; malin.hultberg@slu.se

* Correspondence: omf@isep.ipp.pt

\begin{abstract}
One of the main challenges in both the design of new wastewater treatment plants and the expansion and improvement of existing ones is the removal of emerging pollutants. Therefore, the search for economic and sustainable treatments is needed to enhance the removal of pharmaceuticals. The potential of a lignocellulosic substrate colonized by Pleurotus ostreatus, a waste from mushroom production, to remove fluoxetine from aqueous solutions was studied. Batch assays were performed to remove $600 \mu \mathrm{g} \cdot \mathrm{L}^{-1}$ fluoxetine from aqueous solutions using the colonized mushroom substrate (CMS) and crude enzyme extracts. The removal efficiencies achieved were, respectively, $\geq 83.1 \%$ and $19.6 \%$ in $10 \mathrm{~min}$. Batch assays with sterilized CMS and 1-aminobenzotriazole (to inhibit cytochrome P450 enzymes) showed that the higher removal efficiencies achieved in the CMS assays may be attributed to the synergistic contribution of biosorption onto the CMS and lignin modifying enzymes activity, namely laccase activity. A column assay was performed with the CMS, fed with $750 \mu \mathrm{g} \cdot \mathrm{L}^{-1}$ fluoxetine aqueous solution. The removal efficiency was $100 \%$ during $30 \mathrm{~min}$, decreasing to a final value of $70 \%$ after $8 \mathrm{~h}$ of operation. The results suggested that CMS can be a promising eco-friendly alternative to remove fluoxetine from aqueous solutions.
\end{abstract}

Keywords: crude enzyme extracts; laccase activity; mycoremediation; pharmaceuticals; colonized mushroom substrate; tertiary treatment

\section{Introduction}

Pharmaceuticals (PhCs) are compounds that are highly consumed worldwide and therefore constantly released into aquatic ecosystems as a consequence of human activities and direct discharges from hospitals, pharmaceutical industry, and veterinary facilities, but mainly from urban wastewater treatment plants (WWTPs), which were not specifically designed for PhCs removal [1-3].

The release of PhCs into the aquatic environment is not yet subject to regulation. In Europe, under the Water Framework Directive (WFD), the Surface Water Watch List (WL) (2020) was established, which includes PhCs (erythromycin, clarithromycin and azithromycin, amoxicillin, ciprofloxacin, sulfamethoxazole, trimethoprim, venlafaxine and its metabolite O-desmethylvenlafaxine, and a group of ten azole PhCs) that should be carefully monitored by the European Union member states to determine the risk they pose to the aquatic environment. A Groundwater WL was also implemented by the European Union groundwater working group, who defined a Common Implementation Strategy. The Groundwater WL aims to identify the substances for which groundwater quality standards 
or threshold values should be set. Contrary to the WL for surface water, the monitoring is voluntary. Therefore, it is expected that legal limits will soon be established for the discharge of PhCs into the environment [4] and, simultaneously, a policy to raise public awareness for the correct elimination of excess and/or expired PhCs will be developed.

Even occurring in extremely low concentrations, ranging from $\mu \mathrm{g} \cdot \mathrm{L}^{-1}$ to $\mathrm{ng} \cdot \mathrm{L}^{-1}$ or even lower, concerns have been raised over PhCs' occurrence in the environment because, unlike most pollutants, they are designed to have a specific action on the human body and to act in very low concentrations. Chronic exposure to low concentrations of some PhCs found in the environment can cause adverse effects on human health. Because of these effects, and as $\mathrm{PhCs}$ are not commonly monitored or regulated (by national or international legislation), they are categorized as emerging pollutants [5-8]. There are advanced treatments ready to be used in WWTPs, such as adsorption in activated carbon, membrane filtration, and advanced oxidation processes (e.g., ozonation), but despite their high efficiency, these technologies are often considered expensive and require technical/operational skills and high energy consumption [9]. Aware of this problem, the scientific community has been working to find efficient, economic, and sustainable affination treatment processes for PhCs' removal [10].

One alternative that has gained increasing interest in recent years is mycoremediation, which is a form of bioremediation in which a fungi-based technology is used. Fungi have been proven to be a very cheap, effective, and environmentally sound way of removing a wide array of PhCs from wastewaters [11]. Despite all the potentialities of mycoremediation, before its full-scale application, limitations such as the need for an additional carbon source, immobilization of fungal biomass, competition with autochthonous microorganisms, and high hydraulic retention times need to be overcome [11].

One of the most promising fungal strains in PhCs removal is the edible mushroom Pleurotus ostreatus. Previous studies [10,12-15] have shown that Pleurotus ostreatus can eliminate a wide range of PhCs classes from aqueous solutions. Pleurotus ostreatus is a "white-rot fungi" (WRF) basidiomycete. Its ability to degrade lignin and cellulose, the two main building blocks of plant fibre, is due to the secretion of extracellular ligninmodifying enzymes (LMEs) and acids. Extracellular LMEs include versatile peroxidases (VP, Enzyme Commission (EC) 1.11.1.16), manganese peroxidases (MnP, EC 1.11.1.13), and laccases (phenol oxidases, Lac, EC 1.10.3.2). Unlike other WRF, Pleurotus ostreatus does not produce lignin peroxidases (LiP, EC 1.11.1.14). The main difference between peroxidases and laccases is the electron acceptor, where hydrogen peroxidase and oxygen are the respective electron acceptors [4,16-18]. The composition of the growth medium and culture conditions influence the secretion of a specific enzyme [19-21]. Ligninolytic enzymes are usually produced during secondary metabolism. The synthesis and secretion of these enzymes are often induced by the levels of nutrients (carbon and nitrogen); in addition, the production of $\mathrm{MnP}$ is optimal in high oxygen concentration but is repressed in submerged liquid cultures, while Lac is favoured [22]. Although less studied, intracellular enzymes may play an important role in the degradation of PhCs. Intracellular enzymes or mycelium-associated enzymes (i.e., cytochrome P450 system (CYP450)) are a group of (mainly) monooxygenases that can degrade PhCs by catalyzing several kinds of reactions, such as heteroatom oxygenation, dehalogenation, dealkylation, epoxidation of $\mathrm{C}=\mathrm{C}$, reduction, and hydroxylation [4,12,13,23-25]. The WRF Pleurotus ostreatus has a CYP450 system that consists of 153 genes [12].

The Pleurotus genus is cultivated on a variety of lignocellulosic substrates and various other substrates [26]. After the cultivation, the growing substrate is regarded as waste, known as spent mushroom substrate (SMS). The industrial cultivation of Pleurotus ostreatus and other edible mushrooms produces a significant amount of SMS. In Europe, more than 3.5 million tons of SMS are produced annually [27]. The production of an average of $1 \mathrm{~kg}$ of fresh mushrooms results in $5 \mathrm{~kg}$ of SMS [28,29], being considered an agricultural waste stream. From a circular economy perspective, this agricultural waste is no longer considered a debit entry. Indeed, SMS is currently considered a valuable low-cost and readily available 
resource for different purposes, such as bioremediation of organic pollutants from water matrices, as it harbours high levels of residual enzymatic activity [30-32].

This study aimed to assess the potential of a lignocellulosic substrate colonized by the WRF Pleurotus ostreatus to remove fluoxetine, an antidepressant used worldwide, from aqueous solutions and to evaluate the laccase activity of the colonized mushroom substrate (CMS). Even though fluoxetine is consumed in large amounts [33,34], there are few studies about its degradation using fungi. Batch assays were performed under nonsterile conditions to assess the mechanisms involved in the fluoxetine removal, namely the contribution of the biosorption onto the CMS and of intracellular enzymes activity to fluoxetine removal. Fluoxetine removal using crude enzyme extracts (CEE) (extracellular content without CMS) was also studied. The column assay was performed using the CMS to simulate a tertiary treatment process in a WWTP.

\section{Materials and Methods}

\subsection{Materials}

\subsubsection{Fungal Strain and Cultivation Conditions}

The WRF used in this work was Pleurotus ostreatus M2191 strain. The spawn produced on rye kernels was obtained from Mycelia BVBA (Deinze, Belgium). For cultivation, a mushroom substrate, based on alder sawdust ( $73 \%$ of dry weight $(\mathrm{dw}))$, wheat bran $(25 \%$ of $d w)$, and calcium sulfate ( $2 \%$ of $d w)$, and with a moisture content of $65 \%$, was used. Before inoculation of the spawn, the substrate was packed into gas-permeable bags suitable for mushroom production ( $\mathrm{Sac} \mathrm{O}_{2}$, Nevele, Belgium) and pasteurized at $65^{\circ} \mathrm{C}$ for six hours. The spawn was added in a concentration of $10 \%\left(\mathrm{dw} \cdot \mathrm{dw}^{-1}\right)$ after the substrate had cooled down. The inoculated substrate bags were then incubated at $22{ }^{\circ} \mathrm{C}$ until they were densely colonized by mycelium (fourteen days). The CMS was used directly after fifteen days, being stored cold $\left(10^{\circ} \mathrm{C}\right)$. Before the experiments, the bags were left at room temperature for one day.

\subsubsection{Reagents}

The pharmaceutical fluoxetine hydrochloride ((RS)- $N$-methyl-3-phenyl-3-[4-(trifluoro methyl)phenoxy]propan-1-amine) (purity > 98\%) was obtained from Sigma-Aldrich (Taufkirchen, Germany). The molecular structure of this compound is shown in Figure 1 and its physicochemical properties are listed in Table S1 [35] (Supplementary Materials). The species distribution diagram of fluoxetine as a function of $\mathrm{pH}$ is shown in Figure S1 [36,37] (Supplementary Materials). Stock standard solution of fluoxetine hydrochloride $\left(1300 \mathrm{mg} \cdot \mathrm{L}^{-1}\right)$ was prepared in a basis weight in methanol and stored at $-20{ }^{\circ} \mathrm{C}$ in a dark glass vial.<smiles>CNCCC(Oc1ccc(C(F)(F)F)cc1)c1ccccc1</smiles>

Figure 1. Molecular structure of fluoxetine hydrochloride.

All the working solutions were prepared with HPLC-grade water (resistivity of 18.2 $\mathrm{M} \Omega \cdot \mathrm{cm}^{-1}$ ), obtained from a Simplicity 185 system (Millipore, Molsheim, France).

The information concerning the other reagents used is provided in Table S2 (Supplementary Materials). 


\subsection{Methods}

\subsubsection{Alder Sawdust Characterization}

The $\mathrm{pH}$ at the point of zero charge $\left(\mathrm{pH}_{\mathrm{PZC}}\right)$ and Fourier transmittance infrared (FT-IR) spectrum (Thermo Scientific, Nicolet 6700 FT-IR, MCT/A detector, Waltham, MA, USA) were used to characterize alder sawdust, as described by Silva et al. [38] and Mall et al. [39], respectively. Samples of alder sawdust were ground and dried in an oven (Selecta P, 2000208, Barcelona, Spain) at $70^{\circ} \mathrm{C}$ for $24 \mathrm{~h}$ and cooled in a silica gel desiccator.

\subsubsection{Batch Assays}

Batch assays were performed to study the removal of fluoxetine by the CMS and CEE from non-sterile aqueous solutions. The contributions of biosorption and intracellular enzymes (i.e., CYP450) to the fluoxetine removal were also assessed. The assays were performed at room temperature, for $30 \mathrm{~min}$, continuously stirred at $100 \mathrm{rpm}$ (VELP Scientifica, Multistirrer Magnetic Stirrer F203A0178, Usmate Velate, Italy), and at pH 7 (in BrittonRobinson buffer solution), considering the typical $\mathrm{pH}$ range for domestic wastewater [40] and the expected range after the secondary treatment (between 6.5 and 7.5) [41]. The assays were performed in $250 \mathrm{~mL}$ Erlenmeyer's flasks with a working volume of $150 \mathrm{~mL}$ and an initial concentration of $600 \mu \mathrm{g} \cdot \mathrm{L}^{-1}$ (>30 times higher than the limit of quantification). An initial sample was immediately collected, and further samples were collected at regular time intervals to determine fluoxetine concentration and laccase activity. To stop the enzymatic activity, $40 \mu \mathrm{L}$ of sodium hydroxide $(\mathrm{NaOH})(2 \mathrm{M})$ was added to each sample. Before HPLC-FLD analysis, samples were centrifuged at $9000 \mathrm{rpm}$ (Thermo Scientific, Heraeus Fresco 21 Microcentrifuge, Dreieich, Germany) for $10 \mathrm{~min}$, and the supernatants were collected for analysis. The temperature and $\mathrm{pH}$ (Consort, C861, Turnhout, Belgium) were recorded at the beginning and the end of the assays. Blank assays were run in parallel in the same conditions. All assays were performed in duplicate.

Two CMS assays were performed with $50 \mathrm{~g}$ of the CMS (wet weight, moisture content of $69.9 \pm 1.1 \%$ ) with a fifteen-day lag time (on the first day and after fifteen days of CMS storage, respectively).

The biosorption assays were made with fifty grams of the CMS, previously autoclaved (AJC, Uniclave 88, Portugal) at $120^{\circ} \mathrm{C}$ for $20 \mathrm{~min}$.

The CYP450 inhibition assays were performed after fifteen days of CMS storage, using $50 \mathrm{~g}$ of the CMS previously mixed with a Britton-Robinson buffer solution ( $\mathrm{pH} 7$ ) containing 1-aminobenzotriazole (1-ABT) $(1 \mathrm{mM})$ for $30 \mathrm{~min}$.

The CEE assays were carried out on the first day of storage, using $50 \mathrm{~g}$ of the CMS previously suspended in $150 \mathrm{~mL}$ of Britton-Robinson buffer solution (pH 7). The mixture was incubated at $5{ }^{\circ} \mathrm{C}$ for at least $2 \mathrm{~h}$ and periodically shaken, and then centrifuged at $9000 \times g$ (Heraeus Megafuge 16R Centrifuge, Thermo Fisher Scientific, Waltham, MA, USA) at $5{ }^{\circ} \mathrm{C}$ for $8 \mathrm{~min}$. The supernatant was collected and used as $\mathrm{CEE}$.

\subsubsection{Column Assay}

After three days of storage, a column assay was performed using a glass column (25 mm inner diameter $\times 150 \mathrm{~mm}$ length; Omnifit ${ }^{\circledR}$, Diba Industries, Cambridge, UK), filled with $12.097 \pm 0.001 \mathrm{~g}$ of CMS (wet weight, moisture content of $69.9 \pm 1.1 \%$, bed volume of $4.3 \times 10^{-5} \mathrm{~L}$ ). A $750 \mu \mathrm{g} \cdot \mathrm{L}^{-1}$ non-sterile fluoxetine (hydrochloride) solution in BrittonRobinson buffer ( $\mathrm{pH} 7$ ) was fed to the fixed-bed column using a peristaltic pump (Gilson ${ }^{\circledR}$, Minipuls 3, Villiers le bel, France), with a downward flow rate of $3.0 \pm 0.3 \mathrm{~mL} \cdot \mathrm{min}^{-1}$ (hydraulic flowrate of $4.2 \times 10^{-3} \pm 4.4 \times 10^{-4} \mathrm{~m}^{3} \cdot \mathrm{min}^{-1} \cdot \mathrm{m}^{-2}$ ), at room temperature, operating for $8 \mathrm{~h}$. Samples were taken at regular time intervals to determine fluoxetine concentration and laccase activity in the outlet solution. Like in batch assays, $40 \mu \mathrm{L}$ of $\mathrm{NaOH}(2 \mathrm{M})$ was added to each sample to stop the enzymatic activity. The temperature and $\mathrm{pH}$ of inlet and outlet solutions were also recorded. 


\subsubsection{Determination of CMS Moisture Content}

The moisture content was determined (in triplicate) by weighing $50 \mathrm{~g}$ of the CMS (Metter Toledo ${ }^{\circledR}$, New Classic MF, MS 205DU, Greifensee, Switzerland) before and after drying in an oven at $105^{\circ} \mathrm{C}$ (Selecta P, 2000208, Barcelona, Spain), for $24 \mathrm{~h}$.

\subsubsection{Determination of Laccase Activity}

The laccase (EC 1.10.3.2, p-diphenol: dioxygen oxidoreductase) activity was determined by spectrophotometry as described by Parenti et al. [42].

\subsubsection{Determination of Fluoxetine Concentration}

The quantification of fluoxetine was performed by HPLC-FLD using a Shimadzu LC system (Shimadzu Corporation, Kyoto, Japan) equipped with a LC-20AD pump, a DGU-20A 5R degasser, a CTO-10AS VP column oven, an SIL-20A HT automatic injector, and a RF-20A-XS fluorescence detector. The chromatographic separation was achieved using a Luna C18 column $(150 \times 4.6 \mathrm{~mm}, 5 \mu \mathrm{m}$ particle size) (Phenomenex, Torrance, CA, USA), using the method described by Silva et al. [43]. The identification of the analyte was based on its retention time compared to a standard solution, and the quantification was performed using the external calibration curve method. A linear relationship between peak area and fluoxetine concentration was established in the range of $1-2000 \mu \mathrm{g} \cdot \mathrm{L}^{-1}$. The limit of detection (LOD) and limit of quantification (LOQ) were determined on the basis of the signal-to-noise ratio using the analytical response of 3 and 10 times of the background noise, respectively. The determined LOD and LOQ for fluoxetine were 4.60 and $1.53 \times 10 \mu \mathrm{g} \cdot \mathrm{L}^{-1}$, respectively.

\subsubsection{Statistical Analysis}

Statistical analysis was performed with MedCalc ${ }^{\circledR}$ statistical software (version 12.5.0.0) (Medcalc Software, Ostend, Belgium). The normal distribution of results was tested using the Kolmogorov-Smirnov test, and the outliers' presence was tested using the generalized extreme Studentized deviate (GESD). Removal efficiencies and laccase activities were described as mean \pm standard deviation. Comparison of results was performed with a $t$-test of independent samples (Welch test for unequal variances). The statistical significance was defined as $p$-value $<0.05$.

\section{Results and Discussion}

\subsection{Results of Alder Sawdust Characterization}

FT-IR analysis was performed to identify the functional groups that may act as binding sites in the biosorption of fluoxetine onto alder sawdust. The FT-IR spectrum is shown in Figure 2.

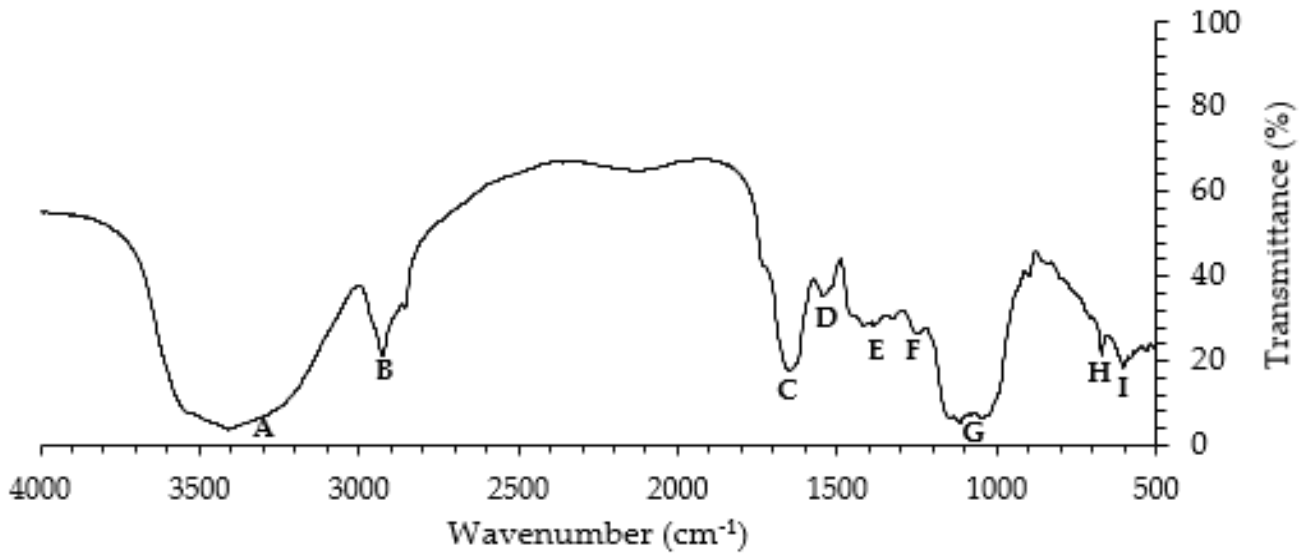

Figure 2. Fourier transform infrared (FT-IR) spectrum of alder sawdust. 
Five main peaks or absorption bands can be identified, and the respective wavenumber assignments are shown in Table S3 (Supplementary Materials). In the functional group region, between 4000 and $2500 \mathrm{~cm}^{-1}$, bands $A$ and $B$ can be identified. The broad and blunt shape absorption band at about $3408 \pm 0 \mathrm{~cm}^{-1}$ (band $\mathrm{A}$ ) is assigned to $\mathrm{O}-\mathrm{H}$ stretching vibrations of water or hydroxyl radicals [44-48]. The absorption band at around $2925 \pm 0 \mathrm{~cm}^{-1}$ (band $\mathrm{B}$ ) is assigned to saturated $\mathrm{C}-\mathrm{H}$ stretching vibrations, more specifically to $\mathrm{CH}_{2}$ asymmetric and symmetric stretching vibrations [44-47]. In the region of double bonds, between 2000 and $1500 \mathrm{~cm}^{-1}$, the sharp shape absorption band at about $1650 \pm 1 \mathrm{~cm}^{-1}$ (band $\mathrm{C}$ ) is assigned to the $\mathrm{C}=\mathrm{O}$ stretching vibration [44,47-49]. The absorption band at about $1539 \pm 3 \mathrm{~cm}^{-1}$ (band D) is assigned to the aromatic $C=C$ deformations [48]. The absorption band at about $1401 \pm 25 \mathrm{~cm}^{-1}$ (band $\mathrm{E}$ ) is assigned to $\mathrm{CH}_{2}$ and $\mathrm{CH}_{3}$ asymmetric deformations [44,48]. The absorption band at about $1238 \pm 1 \mathrm{~cm}^{-1}$ (band F) is assigned to C-O stretching vibrations [48]. In the fingerprint region, below $1300 \mathrm{~cm}^{-1}$, the absorption band at about $1079 \pm 52 \mathrm{~cm}^{-1}$ (band G) is assigned to C-O stretching vibrations $[44,48,49]$. Finally, absorption bands at about $668 \pm 1 \mathrm{~cm}^{-1}$ and $601 \pm 1 \mathrm{~cm}^{-1}$ (bands $\mathrm{H}$ and I, respectively) can be assigned to phenil ring substitutions, certifying the presence of aromatic nuclei in sawdust [48]. Sawdust is mainly composed of cellulose, hemicellulose (xylan and mannosan), and lignin, a non-negligible portion of lipids and waxes, bearing functional groups such as alcohol, ketone, and carboxylic groups [50]. The functional groups that might play an important role in the biosorption mechanism and may be responsible for fluoxetine-binding are hydroxyl, carboxyl, and ketone groups.

The $\mathrm{pH}$ affects the biosorption process, since it determines the speciation of the chemical species. A convenient index of the tendency of a surface to become positively or negatively charged as a function of $\mathrm{pH}$ is the value of $\mathrm{pH}$ that is required for the net charge of the adsorbent to be zero, the so-called zero charge point $\left(\mathrm{pH}_{\mathrm{PZC}}\right)$. The $\mathrm{pH}_{\mathrm{PZC}}$ value determined for alder sawdust was $4.90 \pm 0.01$ (see Figure S2, Supplementary Materials). For $\mathrm{pH}$ values lower than $\mathrm{pH}_{\mathrm{PZC}}$, the surface charge of alder sawdust biomass is positive, and for $\mathrm{pH}$ values above $\mathrm{pH}_{\mathrm{PZC}}$, the surface charge is negative [51].

Fluoxetine hydrochloride has an ionizable amino group with an acid dissociation constant ( $p \mathrm{Ka}$ ) of 9.8 (see Table S1, Supplementary Materials). Figure S1 (Supplementary Materials) shows the species distribution diagram of fluoxetine hydrochloride as a function of $\mathrm{pH}$. It is observed that there are three ranges, with boundaries defined by $\mathrm{pH}=p \mathrm{Ka}-2$ and $\mathrm{pH}=p \mathrm{Ka}+2$ [52]. For $\mathrm{pH}$ values below 7.8, fluoxetine molecules are predominantly positively charged, whereas for $\mathrm{pH}$ values above 11.8 , fluoxetine molecules are predominantly neutral $[36,37]$. In the $\mathrm{pH}$ range between 7.8 and 11.8 , the solution is characterized by the coexistence of neutral and positive species. Thus, attraction forces can be predicted to occur mainly in the $\mathrm{pH}$ range of 4.9-9.8.

\subsection{Results of Batch Assays}

Batch assays were performed to assess the potential of the CMS to remove fluoxetine from aqueous solutions under non-sterile conditions and relate the efficiency to the laccase activity of the CMS. The blank experiments, run in parallel with batch assays, allowed us to verify that about $9 \%$ of fluoxetine concentration was abiotically removed, suggesting potential interactions of the $\mathrm{PhC}$ with the medium. All the removal efficiencies were calculated considering the blank as a reference.

The evolution of fluoxetine concentration and mean laccase activity of CMS tested in the 1st day and after fifteen days of storage (15th day) are shown in Figure 3, where $C_{0}$ $\left(\mu \mathrm{g} \cdot \mathrm{L}^{-1}\right)$ is the initial concentration and $C_{t}\left(\mu \mathrm{g} \cdot \mathrm{L}^{-1}\right)$ is the concentration at a given time. 


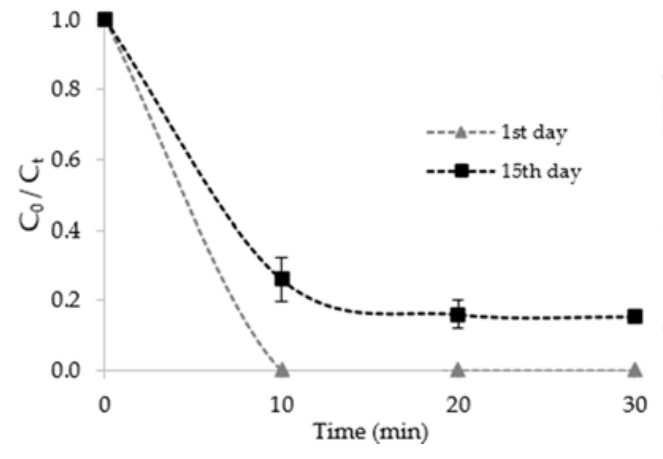

(a)

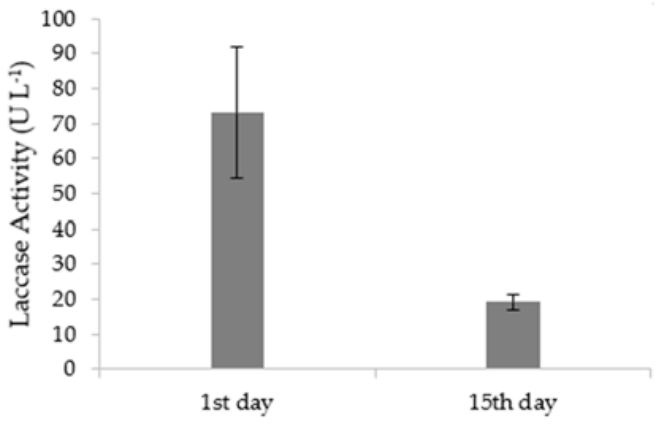

(b)

Figure 3. (a) Progression of fluoxetine concentration and (b) mean laccase activity of colonized mushroom substrate (CMS) at the first day and after fifteen days of storage.

At the beginning of assays, the concentration of fluoxetine was $600 \mu \mathrm{g} \cdot \mathrm{L}^{-1}$, decreasing for both assays on the first $10 \mathrm{~min}$ of the reaction time. After that, the concentration of fluoxetine remained constant. The removal efficiencies achieved for CMS (1st day) and CMS (15th day) assays were $100.0 \pm 0.0 \%$ and $84.6 \pm 0.1 \%$, respectively. The removal efficiencies are statistically different ( $p$-value: 0.01 ), which may be related to the loss of laccase activity over fifteen days of storage, in the range $73.0 \pm 18.7 \mathrm{U} \cdot \mathrm{L}^{-1}-19.2 \pm 2.3 \mathrm{U} \cdot \mathrm{L}^{-1}$ (Figure 3b).

Hultberg et al. [31] studied the removal of diclofenac $\left(2 \mu \mathrm{g} \cdot \mathrm{L}^{-1}\right)$ from water using the same CMS $\left(200 \mathrm{~g} \cdot \mathrm{L}^{-1}\right)$ and related it to the laccase activity of the CMS. A high diclofenac removal efficiency $(80-90 \%)$ in a short period ( $5 \mathrm{~min}$ ) of exposure to the CMS was observed. Similarly to this study, it was observed that diclofenac removal efficiency increased with laccase activity increase. The authors also studied the evolution of laccase activity over time. The results showed that laccase activity significantly decreased during cold storage $\left(10^{\circ} \mathrm{C}\right)$ within four days, reaching the highest level after incubation at $24^{\circ} \mathrm{C}$, immediately before initiation of fruiting body formation. This finding, also confirmed by other research [53,54], suggests a role of the physiological state of Pleurotus ostreatus in the exudation of laccases and that these enzymes have an important role in mycelial growth and nutrient acquisition before fructification. This implies, however, that the use of the CMS should be done immediately (in the very next day) at the WWTP to make this treatment option efficient.

Biosorption and CYP450 inhibition assays were performed to provide insights on the mechanisms involved in the fluoxetine removal by the CMS. The evolution of fluoxetine concentration and mean laccase activity of both assays are shown in Figure 4 . The results of the CMS (15th day) assay are also shown in Figure 4 to establish a comparison.

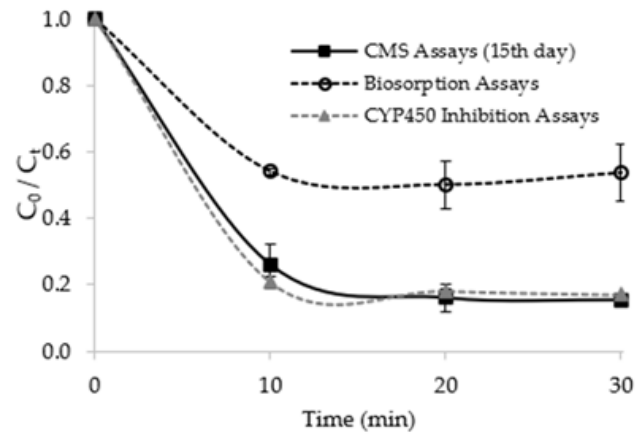

(a)

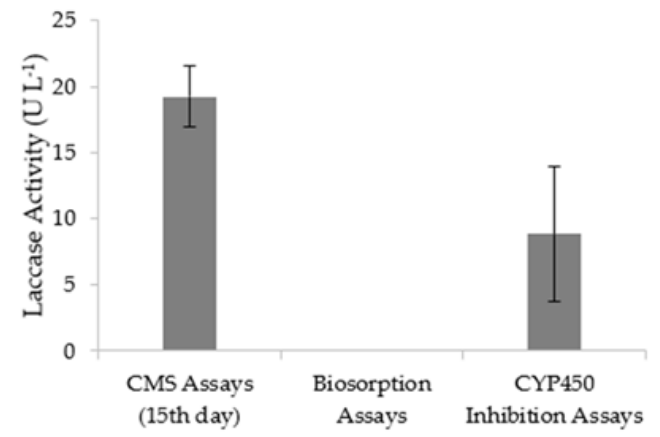

(b)

Figure 4. (a) Progression curves of residual fluoxetine concentration over time and (b) mean laccase activity of the CMS (after 15 days of storage), biosorption, and cytochrome P450 (CYP450) inhibition assays. 
As can be seen in Figure 4a, the fluoxetine removal profiles are similar, with a deep concentration decrease in the first $10 \mathrm{~min}$. The removal efficiencies achieved for biosorption and CYP450 inhibition assays were, respectively, $44.7 \pm 3.5 \%$ and $83.1 \pm 0.7 \%$. Nevertheless, the removal efficiencies of the CMS (15th day) and CYP450 inhibition assays were not statistically different ( $p$-value: 0.14 ), suggesting that CYP450 enzymes' contribution to fluoxetine removal was not relevant, which may be attributed to the fact that the CMS was used immediately before initiation of fruiting body formation. Although the assays were performed using the CMS with the same storage period, the laccase activities (Figure $4 \mathrm{~b}$ ) are statistically different $(19.2 \pm 2.3$ and $8.9 \pm 5.1$ for CMS (15th day) and CYP450 inhibition assays, respectively) ( $p$-value $<0.05)$, probably due to the CMS heterogeneity. On the other hand, the removal efficiencies of the CMS (15th day) and biosorption assays are statistically different ( $p$-value: 0.03 ).

These results suggest that fluoxetine removal efficiency was highly impacted by biosorption $(44.7 \pm 3.5 \%)$ onto the CMS in synergy with LMEs activity. The biosorption of fluoxetine onto the CMS may also have provided a suitable environment for LMEs, probably favouring both biosorbed and dissolved fluoxetine degradation. In addition, some products that result from the alder sawdust and wheat bran degradation may have acted as laccase mediators, enhancing fluoxetine removal efficiency by the CMS. The biosorption of fluoxetine onto the sterilized CMS probably occurred due to its high organic content and functional groups available to interact with fluoxetine [55-57], as a consequence of its components, alder sawdust and wheat bran. As exposed in FT-IR analysis, alder sawdust possesses functional groups that may have a significant potential for fluoxetine binding. The biosorption mechanisms may also have been favoured by the fluoxetine's hydrophobic character $\left(\log \mathrm{K}_{\mathrm{ow}} 4.17\right)$ and because fluoxetine molecules are predominantly positively charged at $\mathrm{pH}$ 6.46-6.94 ( $\mathrm{kKa} 9.8$, see Figure S1, Supplementary Materials), being within the $\mathrm{pH}$ range where attraction forces were predicted to occur (see Section 3.1).

For instance, Zhou et al. [57] demonstrated the ability of an SMS to remove trace concentrations of sulfamethyldiazine, sulfamethazine, sulfathiazole, and sulfamethazole from aqueous solutions.

It is important to note that, in this work, the substrate was previously pasteurized to decrease its microbiota and subsequently inoculate it with spawn. Therefore, the role of the substrate concerning Pleurotus ostreatus was mainly a support and nutrient source. However, it is an agricultural waste and, as such, usually has valuable microbiota (pasteurisation allows survival of spore-producers like Bacillus spp. that may also contribute favourably to the PhCs' biodegradation [58]).

The evolution of residual fluoxetine concentration over the reaction time and mean laccase activity of CEE assays are shown in Figure 5. The results of the CMS (1st day) are also shown in the same figure to establish a comparison. Considering that laccase activities were not statistically different $-73.0 \pm 18.7$ and $80.1 \pm 3.5 \mathrm{U} \cdot \mathrm{L}^{-1}$ for CMS (1st day) and CEE assays, respectively ( $p$-value: 0.40 ) (Figure $5 b$ ) - the higher removal efficiency achieved for CMS (1st day) assays ( $p$-value $<0.05$ ) can be attributed to the biosorption contribution, as discussed before. The fluoxetine removal profiles are also similar (Figure 5a). The removal efficiency achieved for CEE assays was $19.6 \pm 0.9 \%$.

The removal of non-phenolic compounds, such as fluoxetine, by extracellular LMEs is generally poor/unstable. The physicochemical properties of non-phenolic compounds appear to be a key reason for low degradation. Tadkaew et al. [59] inferred that the presence of electron-withdrawing functional groups (EWGs), such as amide, carboxylic, halogen, and nitro, in the molecular structure of compounds, seems to generate an electron deficiency, rendering them less susceptible to oxidative catabolism, thus exhibiting poor removal efficiency. On the opposite side, electron-donating functional groups (EDGs), such as amine, hydroxyl, alkoxy, alkyl, and acyl, render the compounds more prone to the electrophilic attack of aerobic bacteria, thus exhibiting high removal efficiency. Even though fluoxetine contains methyl, ether oxygen, and secondary amine EDGs, it is probable 
that the presence of a trifluoromethyl EWG may hinder laccase-catalyzed degradation (see molecular structure in Figure 1).

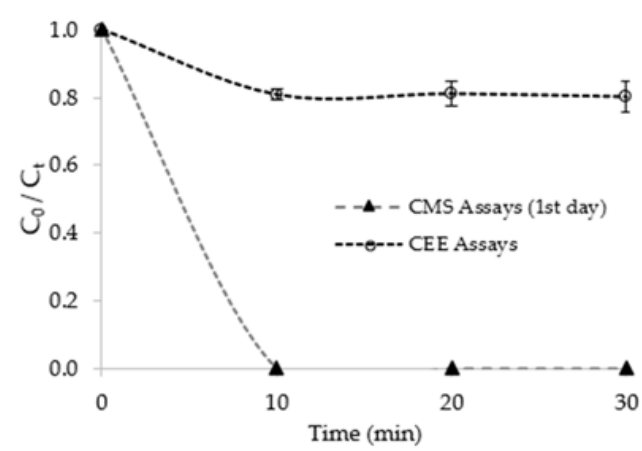

(a)

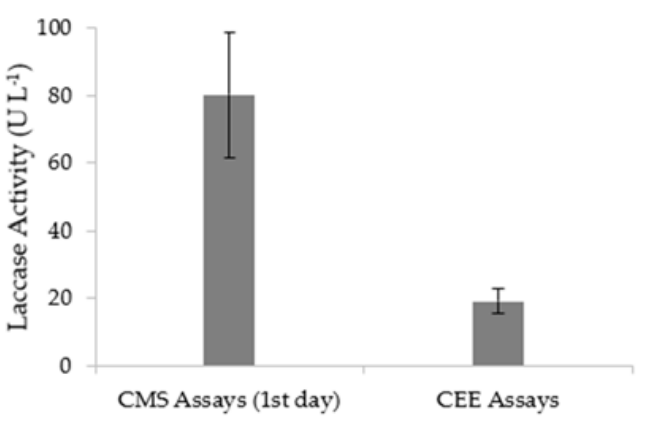

(b)

Figure 5. (a) Progression curves of residual fluoxetine concentration over time and (b) mean laccase activity of the CMS (at the first day) and crude enzyme extracts (CEE) assays.

The laccase activity remained unchanged over the reaction time, which demonstrates that fluoxetine did not harm the stability of the laccase at the assay concentration. Laccases are glycoproteins, glycosylated blue oxidases containing four copper atoms in the active site classified into three types: T1, T2, and T3. The reactions catalyzed by these enzymes proceed by the mono-electronic oxidation of suitable reducing substrates to form reactive radicals at the expense of molecular oxygen, which is eventually reduced to form water molecules. The redox process takes place with the assistance of a cluster of the four copper atoms that form the catalytic core of the enzyme [60]. Due to the low redox potential of the T1 copper, laccase usually oxidizes phenols or phenolic lignin units due to matching redox features [61]. Non-phenolic substrates with redox potential above $1.3 \mathrm{~V}$ are more resistant to mono-electronic oxidation and are not oxidized by laccase directly [62]. The kind of substituents also has an influence on the oxidability. The EWGs, such as trifluoromethyl, may have decreased the possibility for oxidation [63-65]. This seems to limit the relevance of laccase in PhCs removal. However, the presence of redox-mediators in the reaction medium enables laccase to oxidize indirectly non-phenolic substrates [60].

Despite the low fluoxetine removal achieved in this study, when CEE was used, its application on $\mathrm{PhCs}$ ' removal from aqueous solutions has several advantages when compared to the use of live cultures (whole-cell cultures). The degradation of PhCs by WRF is a cometabolic process, which occurs in the presence of an easily degradable substrate, typically glucose [25,66-68]. Extracted LMEs do not need the continuous addition of nutrients or to compete with other microorganisms such as bacteria. Moreover, the use of CEE allows the achievement of high reaction kinetics under mild temperature and $\mathrm{pH}$ conditions [68-71]. Compared to the use of available purified LMEs, the CEE have shown better PhCs removal efficiency, which is attributed to the natural mediators' presence in the CEE [72-74]. In addition, the utilization of crude LMEs PhCs may considerably reduce the cost of the treatment process (as it avoids purification steps). The CEE may, however, contain significant nutrient levels that can increase the organic load of wastewater. The enzymatic degradation combined with other eco-friendly and cost-effective tertiary treatments, such as microalgae-based treatment, may be a possibility to solve this drawback $[4,75,76]$.

Besides the presence of EWG and EDG groups in the molecular structure of fluoxetine and its high ORP, the performance of extracellular LMEs may have been affected by physicochemical properties of the reaction medium, namely by the temperature and $\mathrm{pH}$. The temperature and $\mathrm{pH}$ values recorded in the batch assays (see Table S4, Supplementary Materials) only showed slight variations. Although the assays were performed considering the conditions expected for domestic wastewater after the secondary treatment, these conditions are outside the laccase optimal ranges. 
The temperature acts on enzyme velocity. The effect produced is complex due to the protein nature of enzymes. The temperature increase above a specific value affects the tertiary structure of enzymes and the stability of the enzyme-substrate complex [77]. Pleurotus ostreatus secretes multiple isoforms of laccases. The different Pleurotus ostreatus isoforms have different optimal operating temperatures, $45-65^{\circ} \mathrm{C}$ for POXA1w, $25-35{ }^{\circ} \mathrm{C}$ for POXA2, $35^{\circ} \mathrm{C}$ for POXA3a and POXA3b, and 50-60 ${ }^{\circ} \mathrm{C}$ for POXC $[21,69,78-84]$.

The $\mathrm{pH}$ of the reaction medium determines the charges of the enzyme amino acids. The charge's change is related to conformational changes in the biocatalyst molecule. When the substrate has electrical charges, its approximation to the enzymes' active center also depends on the residual charge involved in the binding. There is, therefore, an optimum $\mathrm{pH}$ value at which the formation of the enzyme-substrate complex is favoured, and the biological activity value is at a maximum [77]. Laccases are generally more stable at acidic $\mathrm{pH}$. Pleurotus ostreatus isoforms have an acid optimal $\mathrm{pH}$ range for 2.6-dimethoxyphenol (2.6-DMP) oxidation, 3.0-5.0 for POXA1w and POXC, 6.5 for POXA2 [84], 5.5-6.5 for POXA3a and POXA3b [83], and 4.5 for POXC1b [21].

\subsection{Results of Column Assays}

The progression curves of residual fluoxetine concentration, laccase activity, and fluoxetine removal efficiency in the column outlet solution over time are shown in Figure 6, where $C_{0}\left(\mu \mathrm{g} \cdot \mathrm{L}^{-1}\right)$ is the inlet solution and $C_{t}\left(\mu \mathrm{g} \cdot \mathrm{L}^{-1}\right)$ is the concentration at a given time.

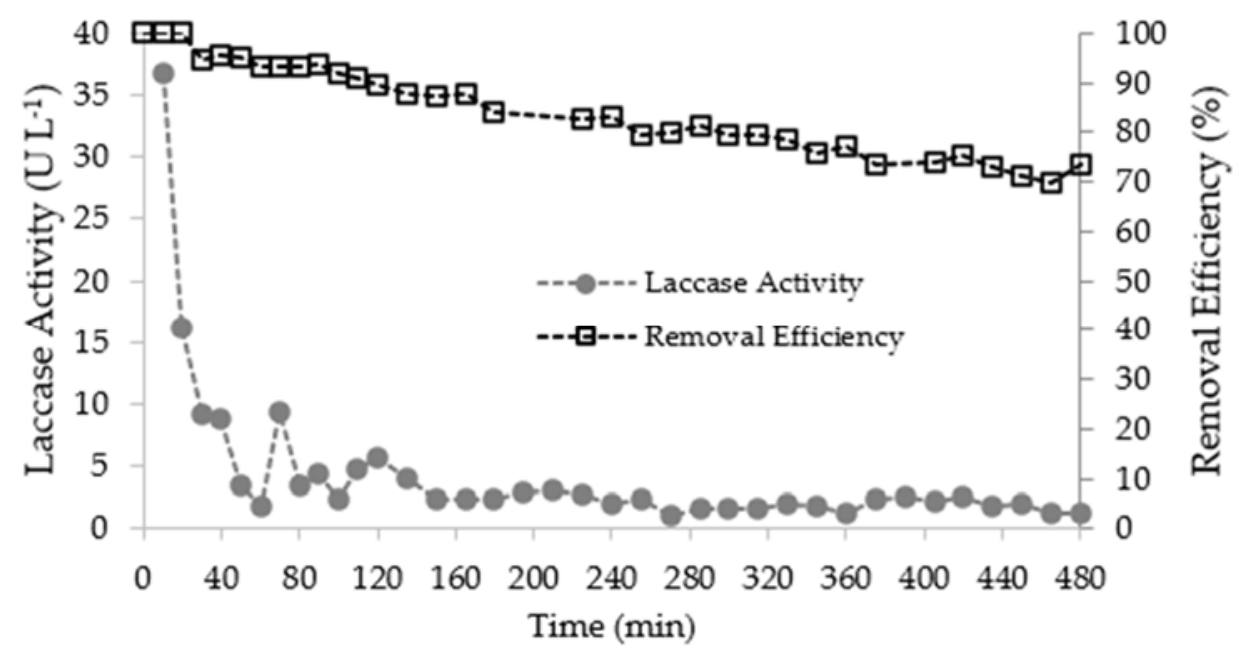

Figure 6. Progression curves of laccase activity and fluoxetine removal efficiency in the column outlet solution over time.

The temperature range of inlet and outlet solutions were, respectively, $13.0-25.0^{\circ} \mathrm{C}$ and $25.5 \pm 0.7^{\circ} \mathrm{C}$. The $\mathrm{pH}$ of inlet and outlet solutions remained stable at, respectively, $7.06 \pm 0.01$ and $6.99 \pm 0.02$.

As shown in Figure 6, fluoxetine was first detected in the outlet solution after $30 \mathrm{~min}$ of operation. The concentration recorded was $37 \pm 2 \mu \mathrm{g} \cdot \mathrm{L}^{-1}$, corresponding to $5 \%$ of the fluoxetine concentration fed to the column. Thereafter, the residual fluoxetine concentration progressively increased until the end of the assay, evidencing a broad mass transfer zone. The theoretical exhaustion point ( $\approx 95 \%$ of the fluoxetine concentration fed to the column), $682 \pm 25 \mu \mathrm{g} \cdot \mathrm{L}^{-1}$, was not achieved. During the eight hours of operation, the removal efficiency achieved was higher than $70 \%$.

Batch assays showed that fluoxetine removal was due to the synergistic effect of LMEs activity, namely the laccase activity and biosorption onto the CMS. The removal efficiency decrease over the operation time may be related to the CMS saturation, the natural LMEs activity decay due to operation conditions, and the permanent washout of natural redoxmediators and LMEs by the flux passing through the column. The laccase activity recorded 
in the outlet solution was at a maximum at the beginning of the assay, $35.8 \mathrm{U} \cdot \mathrm{L}^{-1}$ at $10 \mathrm{~min}$, continuously decreasing until stabilization after $150 \mathrm{~min}$.

Fixed-bed reactors are the most used in continuous processes. They are kinetically more favourable than continuously stirred reactors and do not have high shear stresses due to mechanical stirring. However, there is the possibility of washout of both redox-mediators and LMEs, which may be overcome through enzyme immobilization or by integrating a membrane with a pore size smaller than the size of redox-mediators and LMEs molecules with the fixed-bed reactor. The commonly used approaches for enzyme immobilization (adsorption, covalent binding, entrapment/encapsulation, and cross-linking) imply changes in the enzymes structure or their microenvironment, which is reflected in changes in their catalytic activity and kinetic parameters. To guarantee the use of LMEs in their native form, a membrane may act as a barrier against redox-mediators and LMEs release, while transformation products can cross the membrane along with the treated solution [85]. Nevertheless, further studies are needed to assess the viability of the large-scale treatment process and its potential challenges, such as membrane fouling [86,87].

Furthermore, other factors may affect the LMEs activity and consequently the PhCs removal. Indeed, wastewaters are complex aqueous matrices that contain several organic and inorganic compounds described as laccase activity inhibitors: anions that interact with copper sites (e.g., azide, cyanide, thiocyanide, and fluoride), complexing agents that remove copper from the active site, metal ions (e.g., $\mathrm{Hg}^{2+}$ ), fatty acids, sulfhydryl reagents, hydroxyglycine, and quaternary ammonium cationic washing powders [88-92]. It is also important to note that, in this work, the research was focused on fluoxetine removal rather than degradation pathways and transformation products' toxicity. The toxicity of the treated solution should be assessed before the decision for system scale-up in order to guarantee that the transformation products are not toxic. In previous studies, carbamazepine degradation by-products were found to be more toxic than their parent compound [12,25].

\section{Conclusions}

The ability of a lignocellulosic substrate colonized by the WRF Pleurotus ostreatus and its CEE to remove fluoxetine from aqueous solutions through batch and columns assays were investigated. The removal of fluoxetine by the CMS and CEE under non-sterile conditions was studied in batch systems. The contributions of biosorption and intracellular enzymes (i.e., CYP450) to the fluoxetine removal were also assessed. Fluoxetine removal using crude enzyme extracts (CEE) (extracellular content without CMS) was also performed. All assays were performed at room temperature and $\mathrm{pH} \mathrm{7,} \mathrm{considering} \mathrm{the} \mathrm{expected}$ conditions for treated domestic wastewater (after secondary treatment). High removal efficiencies were achieved with the CMS (1st day) and CMS (15th day), $100.0 \pm 0.0 \%$ and $84.6 \pm 0.1 \%$, respectively, in a short period (10 $\mathrm{min})$. Assays with sterilized CMS and the addition of 1-ABT suggested that the high removal efficiencies achieved were due to the synergistic effects of extracellular LMEs activity, namely as laccase, coupled with sorption onto the CMS. The decrease of removal efficiency observed after fifteen days of storage was related to the loss of laccase activity, in the range $73.0 \pm 18.7 \mathrm{U} \cdot \mathrm{L}^{-1}-19.2 \pm 2.3 \mathrm{U} \cdot \mathrm{L}^{-1}$. A poor removal efficiency was achieved with CEE, $19.6 \pm 0.9 \%$, with a laccase activity of $80.1 \pm 3.5 \mathrm{U} \cdot \mathrm{L}^{-1}$ (statistically equal to the CMS (1st day) assays), which was attributed to the presence of EWGs in the fluoxetine structure, to the high ORP of fluoxetine, and to the operation conditions (temperature and $\mathrm{pH}$ ) outside the optimal range.

A fixed-bed column assay was performed using the CMS, which showed a good performance over the eight hours of continuous operation. The removal efficiency achieved was complete during approximately thirty minutes, then it decreased progressively over time to a final value of $70 \%$, after $8 \mathrm{~h}$ of operation. However, the laccase activity was recorded in the treated solution, suggesting the need to couple, for instance, a membrane with a suitable pore size to avoid LMEs washout. 
The results obtained suggest that CMS use is a good candidate for fluoxetine removal as a tertiary treatment of wastewaters, being an eco-friendly alternative that allows the valorization of waste from the food industry.

Nevertheless, further investigation is needed to better evaluate technical, economic, and environmental aspects before application of the CMS to real wastewater.

Supplementary Materials: The following supporting information can be downloaded at: https: / / www.mdpi.com/article/10.3390/ijerph19052672/s1, Figure S1: Species distribution diagram of fluoxetine as a function of $\mathrm{pH}$ (adapted from [2,3]), Figure S2: The point of zero charge (pHPZC) determination in alder sawdust, Table S1: Physicochemical properties of fluoxetine hydrochloride, Table S2: List of reagents used in the study, Table S3: Band assignments of FT-IR spectrum of alder sawdust, Table S4: $\mathrm{pH}$ and temperature values recorded at the beginning and the end of batch assays.

Author Contributions: Conceptualization, O.M.F., M.H. and S.A.F.; funding acquisition, M.H. and C.D.-M.; investigation, A.D.M.S. and J.S.; methodology, A.D.M.S., O.M.F., M.H. and S.A.F.; project administration, M.H. and C.D.-M.; resources, M.H. and C.D.-M.; supervision, O.M.F., M.H., S.A.F. and C.D.-M.; visualization, M.H.; writing-original draft, A.D.M.S.; writing-review and editing O.M.F., M.H., S.A.F. and C.D.-M. All authors have read and agreed to the published version of the manuscript.

Funding: This research was funded by the Associate Laboratory for Green Chemistry-LAQV, which received financial support from UIDB/50006/2020, UIDP/50006/2020, and LA/P/0008/2020 by the Fundação para a Ciência e a Tecnologia (FCT)/Ministério da Ciência, Tecnologia e Ensino Superior (MCTES) through national funds. This research was also funded by the EU and FCT/UEFISCDI/FORMAS, in the frame of the collaborative international consortium REWATER"Sustainable and safe water management in agriculture: increasing the efficiency of water reuse for crop growth while protecting ecosystems, services and citizens' welfare" (WaterJPI/0007/2016), which was financed under the ERA-NET Cofund WaterWorks2015 Call, as an integral part of the 2016 Joint Activities developed by the Water Challenges for a Changing World Joint Program Initiative (Water JPI). The research was funded also by the ERA-NET Cofund BiodivRestore-DivRestore/002/2020, BioReset-“Biodiversity restoration and conservation of inland water ecosystems for environmental and human well-being", BiodivRestore 2020-2021 Call. A.D.M. Silva would like to thank FCT for her Ph.D. Grant SFRH/BD/138/780/2018. The authors are greatly indebted to all financing sources.

Institutional Review Board Statement: Not applicable.

Informed Consent Statement: Not applicable.

Data Availability Statement: Not applicable.

Conflicts of Interest: The authors declare no conflict of interest.

\section{References}

1. Arnold, K.E.; Brown, A.R.; Ankley, G.T.; Sumpter, J.P. Medicating the environment: Assessing risks of pharmaceuticals to wildlife and ecosystems. Philos. Trans. R. Soc. Lond. B. Biol. Sci. 2014, 369, 20130569. [CrossRef] [PubMed]

2. Kim, K.-R.; Owens, G.; Kwon, S.-I.; So, K.-H.; Lee, D.-B.; Ok, Y.S. Occurrence and Environmental Fate of Veterinary Antibiotics in the Terrestrial Environment. Water Air Soil Pollut. 2010, 214, 163-174. [CrossRef]

3. Ji, K.; Kim, S.; Han, S.; Seo, J.; Lee, S.; Park, Y.; Choi, K.; Kho, Y.-L.; Kim, P.-G.; Park, J.; et al. Risk assessment of chlortetracycline, oxytetracycline, sulfamethazine, sulfathiazole, and erythromycin in aquatic environment: Are the current environmental concentrations safe? Ecotoxicology 2012, 21, 2031-2050. [CrossRef] [PubMed]

4. Silva, A.; Delerue-Matos, C.; Figueiredo, S.A.; Freitas, O.M. The Use of Algae and Fungi for Removal of Pharmaceuticals by Bioremediation and Biosorption Processes: A Review. Water 2019, 11, 1555. [CrossRef]

5. Boxall, A.B.A.; Rudd, M.A.; Brooks, B.W.; Caldwell, D.J.; Choi, K.; Hickmann, S.; Innes, E.; Ostapyk, K.; Staveley, J.P.; Verslycke, T.; et al. Pharmaceuticals and Personal Care Products in the Environment: What Are the Big Questions? Environ. Health Perspect. 2012, 120, 1221-1229. [CrossRef]

6. Paíga, P.; Santos, L.H.M.L.M.; Amorim, C.G.; Araújo, A.N.; Montenegro, M.C.B.S.M.; Pena, A.; Delerue-Matos, C. Pilot monitoring study of ibuprofen in surface waters of north of Portugal. Environ. Sci. Pollut. Res. Int. 2013, 20, 2410-2420. [CrossRef]

7. Paiga, P.; Santos, L.H.M.L.M.; Ramos, S.; Jorge, S.; Silva, J.G.; Delerue-Matos, C. Presence of pharmaceuticals in the Lis river (Portugal): Sources, fate and seasonal variation. Sci. Total Environ. 2016, 573, 164-177. [CrossRef]

8. UNESCO. Emerging Pollutants in Water and Wastewater. Available online: https://en.unesco.org/emergingpollutantsinwaterand wastewater (accessed on 13 December 2021). 
9. Wu, S.; Zhang, L.; Chen, J. Paracetamol in the environment and its degradation by microorganisms. Appl. Microbiol. Biotechnol. 2012, 96, 875-884. [CrossRef]

10. Wen, X.; Jia, Y.; Li, J. Enzymatic degradation of tetracycline and oxytetracycline by crude manganese peroxidase prepared from Phanerochaete chrysosporium. J. Hazard. Mater. 2010, 177, 924-928. [CrossRef]

11. Lindsey, B. Biodegradation and Bioremediation, 1st ed.; ED-Tech Press: Waltham Abbey, UK, 2018; ISBN 9781839473425.

12. Golan-Rozen, N.; Chefetz, B.; Ben-Ari, J.; Geva, J.; Hadar, Y. Transformation of the recalcitrant pharmaceutical compound carbamazepine by Pleurotus ostreatus: Role of cytochrome P450 monooxygenase and manganese peroxidase. Environ. Sci. Technol. 2011, 45, 6800-6805. [CrossRef]

13. Palli, L.; Castellet-Rovira, F.; Pérez-Trujillo, M.; Caniani, D.; Sarrà-Adroguer, M.; Gori, R. Preliminary evaluation of Pleurotus ostreatus for the removal of selected pharmaceuticals from hospital wastewater. Biotechnol. Prog. 2017, 33, 1529-1537. [CrossRef] [PubMed]

14. Křesinová, Z.; Moeder, M.; Ezechiáš, M.; Svobodová, K.; Cajthaml, T. Mechanistic study of 17alpha-ethinylestradiol biodegradation by Pleurotus ostreatus: Tracking of extracelullar and intracelullar degradation mechanisms. Environ. Sci. Technol. 2012, 46, 13377-13385. [CrossRef] [PubMed]

15. Asif, M.B.; Hai, F.I.; Singh, L.; Price, W.E.; Nghiem, L.D. Degradation of Pharmaceuticals and Personal Care Products by White-Rot Fungi-A Critical Review. Curr. Pollut. Rep. 2017, 3, 88-103. [CrossRef]

16. Janusz, G.; Kucharzyk, K.H.; Pawlik, A.; Staszczak, M.; Paszczynski, A.J. Fungal laccase, manganese peroxidase and lignin peroxidase: Gene expression and regulation. Enzyme Microb. Technol. 2013, 52, 1-12. [CrossRef] [PubMed]

17. Fernandez-Fueyo, E.; Castanera, R.; Ruiz-Dueñas, F.J.; López-Lucendo, M.F.; Ramírez, L.; Pisabarro, A.G.; Martínez, A.T. Ligninolytic peroxidase gene expression by Pleurotus ostreatus: Differential regulation in lignocellulose medium and effect of temperature and pH. Fungal Genet. Biol. 2014, 72, 150-161. [CrossRef]

18. Knop, D.; Yarden, O.; Hadar, y. The ligninolytic peroxidases in the genus Pleurotus: Divergence in activities, expression, and potential applications. Appl. Microbiol. Biotechnol. 2015, 99, 1025-1038. [CrossRef] [PubMed]

19. Pointing, S.B. Feasibility of bioremediation by white-rot fungi. Appl. Microbiol. Biotechnol. 2001, 57, 20-33. [CrossRef]

20. Guillén, F.; Gómez-Toribio, V.; Martínez, M.J.; Martínez, A.T. Production of hydroxyl radical by the synergistic action of fungal laccase and aryl alcohol oxidase. Arch. Biochem. Biophys. 2000, 383, 142-147. [CrossRef]

21. Giardina, P.; Palmieri, G.; Scaloni, A.; Fontanella, B.; Faraco, V.; Cennamo, G.; Sannia, G. Protein and gene structure of a blue laccase from Pleurotus ostreatus. Biochem. J. 1999, 341, 655-663. [CrossRef]

22. Wesenberg, D.; Kyriakides, I.; Agathos, S.N. White-rot fungi and their enzymes for the treatment of industrial dye effluents. Biotechnol. Adv. 2003, 22, 161-187. [CrossRef]

23. Bernhardt, R. Cytochromes P450 as versatile biocatalysts. J. Biotechnol. 2006, 124, 128-145. [CrossRef] [PubMed]

24. Lu, T.; Zhang, Q.-L.; Yao, S.-J. Application of Biosorption and Biodegradation Functions of Fungi in Wastewater and Sludge Treatment. In Fungal Applications in Sustainable Environmental Biotechnology; Purchase, D., Ed.; Springer: Cham, Switzerland, 2016; pp. 65-90. ISBN 9783319428505.

25. Jelic, A.; Cruz-Morató, C.; Marco-Urrea, E.; Sarrà, M.; Perez, S.; Vicent, T.; Petrović, M.; Barcelo, D. Degradation of carbamazepine by Trametes versicolor in an air pulsed fluidized bed bioreactor and identification of intermediates. Water Res. 2012, 46, 955-964. [CrossRef] [PubMed]

26. Cohen, R.; Persky, L.; Hadar, Y. Biotechnological applications and potential of wood-degrading mushrooms of the genus Pleurotus. Appl. Microbiol. Biotechnol. 2002, 58, 582-594. [CrossRef] [PubMed]

27. Gea, F.J.; Carrasco, J.; Diánez, F.; Santos, M.; Navarro, M.J. Control of dry bubble disease (Lecanicillium fungicola) in button mushroom (Agaricus bisporus) by spent mushroom substrate tea. Eur. J. Plant Pathol. 2014, 138, 711-720. [CrossRef]

28. Chagas, E.P.; Durrant, L.R. Decolorization of azo dyes by Phanerochaete chrysosporium and Pleurotus sajorcaju. Enzyme Microb. Technol. 2001, 29, 473-477. [CrossRef]

29. Finney, K.N.; Ryu, C.; Sharifi, V.N.; Swithenbank, J. The reuse of spent mushroom compost and coal tailings for energy recovery: Comparison of thermal treatment technologies. Bioresour. Technol. 2009, 100, 310-315. [CrossRef]

30. Grimm, D.; Wösten, H.A.B. Mushroom cultivation in the circular economy. Appl. Microbiol. Biotechnol. 2018, 102, 7795-7803. [CrossRef]

31. Hultberg, M.; Ahrens, L.; Golovko, O. Use of lignocellulosic substrate colonized by oyster mushroom (Pleurotus ostreatus) for removal of organic micropollutants from water. J. Environ. Manag. 2020, 272, 111087. [CrossRef]

32. Chiu, S.W.; Law, S.C.; Ching, M.L.; Cheung, K.W.; Chen, M.J. Themes for mushroom exploitation in the 21st century: Sustainability, waste management, and conservation. J. Gen. Appl. Microbiol. 2000, 46, 269-282. [CrossRef]

33. Neuwoehner, J.; Fenner, k.; Escher, B.I. Physiological modes of action of fluoxetine and its human metabolites in algae. Environ. Sci. Technol. 2009, 43, 6830-6837. [CrossRef]

34. Olfson, M.; Marcus, S.C.; Pincus, H.A.; Zito, J.M.; Thompson, J.W.; Zarin, D.A. Antidepressant prescribing practices of outpatient psychiatrists. Arch. Gen. Psychiatry 1998, 55, 310-316. [CrossRef] [PubMed]

35. ChemAxon. Marvin Software. Available online: https://chemaxon.com (accessed on 10 January 2019).

36. Schneider, J.D. pH Effects on the Sorption of Fluoxetine and Sulfamethoxazole by Three Powdered Activated Carbons, in Civil and Environmental Engineering. Master's Thesis, Utah State University, Logan, UT, USA, May 2018. 
37. Beardall, J. The Fate of Pharmaceuticals and Personal Care Products in Conventional and Engineered On-Site Wastewater Drain Fields, in Civil and Environmental Engineering. Master's Thesis, Utah State University, Logan, UT, USA, May 2015.

38. Silva, A.; Coimbra, R.N.; Escapa, C.; Figueiredo, S.A.; Freitas, O.M.; Otero, M. Green Microalgae Scenedesmus Obliquus Utilization for the Adsorptive Removal of Nonsteroidal Anti-Inflammatory Drugs (NSAIDs) from Water Samples. Int. J. Environ. Res. Public Health 2020, 17, 3707. [CrossRef] [PubMed]

39. Mall, I.D.; Srivastava, V.C.; Kumar, G.V.A.; Mishra, I.M. Characterization and utilization of mesoporous fertilizer plant waste carbon for adsorptive removal of dyes from aqueous solution. Colloids Surf. A Physicochem. Eng. Asp. 2006, 278, 175-187. [CrossRef]

40. Wastewater Connect. Available online: http://wastewaterconnect.co.za/wastewater-info-hub-entry?id=12 (accessed on 6 March 2020).

41. Metcalf \& Eddy, Inc.; Tchobanoglous, G.; Burton, F.; Stensel, H.D. Wastewater Engineering: Treatment and Reuse; McGraw-Hill Education: New York, NY, USA, 2003; ISBN 9780070418783.

42. Parenti, A.; Muguerza, E.; Iroz, A.R.; Omarini, A.; Conde, E.; Alfaro, M.; Castanera, R.; Santoyo, F.; Ramírez, L.; Pisabarro, A.G. Induction of laccase activity in the white rot fungus Pleurotus ostreatus using water polluted with wheat straw extracts. Bioresour. Technol. 2013, 133, 142-149. [CrossRef] [PubMed]

43. Silva, A.; Stawinski, W.; Romacho, J.; Santos, L.H.M.L.M.; Figueiredo, S.A.; Freitas, O.M.; Delerue-Matos, C. Adsorption of Fluoxetine and Venlafaxine onto the Marine Seaweed Bifurcaria bifurcata. Environ. Eng. Sci. 2019, 36, 573-582. [CrossRef]

44. Wahab, M.A.; Jellali, S.; Jedidi, N. Ammonium biosorption onto sawdust: FTIR analysis, kinetics and adsorption isotherms modeling. Bioresour. Technol. 2010, 101, 5070-5075. [CrossRef]

45. Bajpai, S.K.; Bajpai, M.; Rai, N. Sorptive removal of ciprofloxacin hydrochloride from simulated wastewater using sawdust: Kinetic study and effect of $\mathrm{pH}$. Water $S A$ 2012, 38, 5. [CrossRef]

46. Abdullah, R.H.; Oda, A.M.; Omran, A.R.; Mottaleb, A.S.; Mubarakah, T.M. Study of Adsorption Characteristics a Low-Cost Sawdust for the Removal of Direct Blue 85 Dye from Aqueous Solutions. Indones. J. Chem. 2018, 18. [CrossRef]

47. Saha, T.K.; Bishwas, R.K.; Karmaker, S.; Islam, Z. Adsorption Characteristics of Allura Red AC onto Sawdust and Hexadecylpyridinium Bromide-Treated Sawdust in Aqueous Solution. ACS Omega 2020, 5, 13358-13374. [CrossRef]

48. Dirckx, O.; Trouy, M.-C.; Merlin, A.; Deglise, X. Modifications de la couleur du bois d'Abies grandis exposé à la lumière solaire. Ann. Sci. For. 1992, 49, 425-447. [CrossRef]

49. Jaya, H.; Omar, M.F.; Akil, H.M.; Ahmad, Z.A.; Zulkepli, N.N. Effect of Alkaline Treatment on Sawdust Reinforced High Density Polyethylene Composite under Wide Strain Rate. Mater. Sci. Forum 2016, 840, 103-107. [CrossRef]

50. Gnanasambandam, R.; Proctor, A. Determination of pectin degree of esterification by diffuse reflectance Fourier transform infrared spectroscopy. Food Chem. 2000, 68, 327-332. [CrossRef]

51. Ayranci, E.; Hoda, N.; Bayram, E. Adsorption of benzoic acid onto high specific area activated carbon cloth. J. Colloid Interface Sci. 2005, 284, 83-88. [CrossRef] [PubMed]

52. Worch, E. Adsorption Technology in Water Treatment: Fundamentals, Processes, and Modeling; De Gruyter: Berlin, Germany, 2012; ISBN 9783110240221.

53. Kurt, S.; Buyukalaca, S. Yield performances and changes in enzyme activities of Pleurotus spp. (P. ostreatus and P. sajor-caju) cultivated on different agricultural wastes. Bioresour. Technol. 2010, 101, 3164-3169. [CrossRef]

54. Suguimoto, H.H.; Barbosa, A.M.; Dekker, R.F.H.; Castro-Gomez, R.J.H. Veratryl alcohol stimulates fruiting body formation in the oyster mushroom, Pleurotus ostreatus. FEMS Microbiol. Lett. 2001, 194, 235-238. [CrossRef]

55. Álvarez-Martín, A.; Rodríguez-Cruz, M.S.; Andrades, M.S.; Sánchez-Martín, M.J. Application of a biosorbent to soil: A potential method for controlling water pollution by pesticides. Environ. Sci. Pollut. Res. 2016, 23, 9192-9203. [CrossRef]

56. García-Delgado, C.; Marín-Benito, J.M.; Sánchez-Martín, M.J.; Rodríguez-Cruz, M.S. Organic carbon nature determines the capacity of organic amendments to adsorb pesticides in soil. J. Hazard. Mater. 2020, 390, 122162. [CrossRef]

57. Zhou, A.; Zhang, Y.; Lui, R.; Su, X.; Zhang, L. Adsorptive removal of sulfa antibiotics from water using spent mushroom substrate, an agricultural waste. Desalination Water Treat. 2016, 57, 388-397. [CrossRef]

58. Chang, B.-V.; Fan, S.-N.; Tsai, Y.-C.; Chung, Y.-L.; Tu, P.-X.; Yang, C.-W. Removal of emerging contaminants using spent mushroom compost. Sci. Total Environ. 2018, 634, 922-933. [CrossRef]

59. Tadkaew, N.; Hai, F.I.; McDonald, J.A.; Khan, S.J.; Nghiem, L.D. Removal of trace organics by MBR treatment: The role of molecular properties. Water Research. 2011, 45, 2439-2451. [CrossRef]

60. Riva, S. Laccases: Blue enzymes for green chemistry. Trends Biotechnol. 2006, 24, 219-226. [CrossRef] [PubMed]

61. Kroneck, P.M.H. Redox Properties of Blue Multi-Copper Oxidases. In Multi-Copper Oxidases; Messerschmidt, A., Ed.; World Scientific Publishing Company: London, UK, 1997; ISBN 9810227116.

62. Morozova, O.V.; Shumakovich, G.P.; Shleev, S.V.; Yaropolov, Y.I. Laccase-mediator systems and their applications: A review. Appl. Biochem. Microbiol. 2007, 43, 523-535. [CrossRef]

63. Xu, F.; Kulys, J.J.; Duke, K.; Li, K.; Krikstopaitis, K.; Deussen, H.-J.W.; Abbate, E.; Galinyte, V.; Schneider, P. Redox chemistry in laccase-catalyzed oxidation of N-hydroxy compounds. Appl. Environ. Microbiol. 2000, 66, 2052-2056. [CrossRef] [PubMed]

64. Tadesse, M.A.; D'Annibale, A.; Galli, C.; Gentilia, P.; Sergia, F. An assessment of the relative contributions of redox and steric issues to laccase specificity towards putative substrates. Org. Biomol. Chem. 2008, 6, 868-878. [CrossRef] [PubMed] 
65. Hahn, V.; Mikolasch, A.; Schauer, F. Cleavage and synthesis function of high and low redox potential laccases towards 4morpholinoaniline and aminated as well as chlorinated phenols. Appl. Microbiol. Biotechnol. 2014, 98, 1609-1620. [CrossRef]

66. Rodarte-Morales, A.I.; Feijoo, G.; Moreira, M.T.; Lema, J.M. Operation of stirred tank reactors (STRs) and fixed-bed reactors (FBRs) with free and immobilized Phanerochaete chrysosporium for the continuous removal of pharmaceutical compounds. Biochem. Eng. J. 2012, 66, 38-45. [CrossRef]

67. Rodarte-Morales, A.I.; Feijoo, G.; Moreira, M.T.; Lema, J.M. Biotransformation of three pharmaceutical active compounds by the fungus Phanerochaete chrysosporium in a fed batch stirred reactor under air and oxygen supply. Biodegradation 2012, $23,145-156$. [CrossRef]

68. Blánquez, P.; Guieysse, B. Continuous biodegradation of 17beta-estradiol and 17alpha-ethynylestradiol by Trametes versicolor. J. Hazard. Mater. 2008, 150, 459-462. [CrossRef]

69. Baldrian, P. Fungal laccases-Occurrence and properties. FEMS Microbiol. Rev. 2006, 30, 215-242. [CrossRef]

70. de Cazes, M.; Abejón, R.; Belleville, M.-P.; Sanchez-Marcano, J. Membrane bioprocesses for pharmaceutical micropollutant removal from waters. Membranes 2014, 4, 692-729. [CrossRef]

71. Demarche, P.; Junghanns, C.; Nair, R.R.; Agathos, S.N. Harnessing the power of enzymes for environmental stewardship. Biotechnol. Adv. 2012, 30, 933-953. [CrossRef] [PubMed]

72. Tran, N.H.; Urase, T.; Kusakabe, O. Biodegradation characteristics of pharmaceutical substances by whole fungal culture Trametes versicolor and its laccase. J. Water Environ. Technol. 2010, 8, 125-140. [CrossRef]

73. Lloret, L.; Eibes, G.; Lú-Chau, T.A.; Moreira, M.T.; Feijoo, G.; Lema, J.M. Laccase-catalyzed degradation of anti-inflammatories and estrogens. Biochem. Eng. J. 2010, 51, 124-131. [CrossRef]

74. Nguyen, L.N.; Hai, F.I.; Price, W.E.; Kang, J.; Leusch, F.D.L.; Roddick, F.; van de Merwe, J.P.; Magram, S.F.; Nghiem, L.D Degradation of a broad spectrum of trace organic contaminants by an enzymatic membrane reactor: Complementary role of membrane retention and enzymatic degradation. Int. Biodeterior. Biodegrad. 2015, 99, 115-122. [CrossRef]

75. Nguyen, L.N.; van de Merwe, J.P.; Hai, F.I.; Leusch, F.D.L.; Kang, J.; Price, W.E.; Roddick, F.; Magram, S.F.; Nghiem, L.D Laccase-syringaldehyde-mediated degradation of trace organic contaminants in an enzymatic membrane reactor: Removal efficiency and effluent toxicity. Bioresour. Technol. 2016, 200, 477-484. [CrossRef] [PubMed]

76. Raja, R.; Hemaiswarya, S.; Kumar, N.A.; Sridhar, S.; Rengasamy, R. A perspective on the biotechnological potential of microalgae. Crit. Rev. Microbiol. 2008, 34, 77-88. [CrossRef] [PubMed]

77. Bisswanger, H. Enzyme Kinetics: Principles and Methods, 3rd ed.; Wiley-VCH: Weinheim, Germany, 2017; Chapter 6; pp. 145-152. ISBN 9783527342518

78. Kumar, A.; Chandra, R. Ligninolytic enzymes and its mechanisms for degradation of lignocellulosic waste in environment. Heliyon 2020, 6, e03170. [CrossRef] [PubMed]

79. Jureczko, M.; Przystaś, W. Pleurotus ostreatus and Trametes versicolor, Fungal Strains as Remedy for Recalcitrant Pharmaceuticals Removal Current Knowledge and Future Perspectives. Biomed. J. Sci. Tech. Res. 2018, 3. [CrossRef]

80. Fernández-Fueyo, E.; Ruiz-Dueñas, F.J.; Martínez, M.J.; Romero, A.; Hammel, K.E.; Medrano, F.J.; Martínez, A.T. Ligninolytic peroxidase genes in the oyster mushroom genome: Heterologous expression, molecular structure, catalytic and stability properties, and lignin-degrading ability. Biotechnol. Biofuels 2014, 7, 2. [CrossRef] [PubMed]

81. Raghukumar, C.; Raghukumar, S.; Chinnaraj, A.; Chandramohan, D.; D'Souza, T.M.; Reddy, C.A. Laccase and Other Lignocellulose Modifying Enzymes of Marine Fungi Isolated from the Coast of India. Bot. Mar. 1994, 37, 515-523. [CrossRef]

82. Schneider, P.; Caspersen, M.; Mondorf, K.; Halkier, T.; Skov, L.; Østergaard, P.; Brown, K.; Brown, S.H.; Xu, F. Characterization of a Coprinus cinereus laccase. Enzym. Microb. Technol. 1999, 25, 502-508. [CrossRef]

83. Palmieri, G.; Cennamo, G.; Faraco, V.; Amoresano, A.; Sannia, G.; Giardina, P. Atypical laccase isoenzymes from copper supplemented Pleurotus ostreatus cultures. Enzym. Microb. Technol. 2003, 33, 220-230. [CrossRef]

84. Palmieri, G.; Giardina, P.; Bianco, C.; Scaloni, A.; Capasso, A.; Sannia, G. A novel white laccase from Pleurotus ostreatus. J. Biol. Chem. 1997, 272, 31301-31307. [CrossRef] [PubMed]

85. Yaropolov, A.I.; Skorobogat'ko, O.V.; Vartanov, S.S.; Varfolomeyev, S.D. Laccase: Properties, catalytic mechanism, and applicability. Appl. Biochem. Biotechnol. 1994, 49, 257-280. [CrossRef]

86. Nghiem, L.D.; Coleman, P.J.; Espendiller, C. Mechanisms underlying the effects of membrane fouling on the nanofiltration of trace organic contaminants. Desalination 2010, 250, 682-687. [CrossRef]

87. Al-Maqdi, K.A.; Elmerhi, N.; Athamneh, K.; Bilal, M.; Alzamly, A.; Ashraf, S.S.; Shah, I. Challenges and Recent Advances in Enzyme-Mediated Wastewater Remediation-A Review. Nanomaterials 2021, 11, 3124. [CrossRef] [PubMed]

88. Hu, X.; Wang, C.; Wang, L.; Zhang, R.; Chen, H. Influence of temperature, $\mathrm{pH}$ and metal ions on guaiacol oxidation of purified laccase from Leptographium qinlingensis. World J. Microbiol. Biotechnol. 2014, 30, 1285-1290. [CrossRef]

89. D'Souza-Ticlo, D.; Sharma, D.; Raghukumar, C. A thermostable metal-tolerant laccase with bioremediation potential from a marine-derived fungus. Mar. Biotechnol. 2009, 11, 725-737. [CrossRef]

90. Wan, J.; Zeng, G.; Huang, D.; Huang, C.; Lai, C.; Li, N.; Wei, Z.; Xu, P.; He, X.; Lai, M.; et al. The oxidative stress of Phanerochaete chrysosporium against lead toxicity. Appl. Biochem. Biotechnol. 2015, 175, 1981-1991. [CrossRef] 
91. Gianfreda, L.; Sannino, F.; Filazzola, M.T.; Leonowicz, A. Catalytic behavior and detoxifying ability of a laccase from the fungal strain Cerrena unicolor. J. Mol. Catal. B Enzym. 1998, 4, 13-23. [CrossRef]

92. $\mathrm{Xu}, \mathrm{F}$. Oxidation of phenols, anilines, and benzenethiols by fungal laccases: Correlation between activity and redox potentials as well as halide inhibition. Biochemistry 1996, 35, 7608-7614. [CrossRef] [PubMed] 